\title{
The Vulnerability of Damaged River and Lake Dikes for Wave Overtopping
}

\author{
Vera M. van Bergeijk ${ }^{1, a}$, Vincent A. Verdonk ${ }^{1,2}$, Jord J. Warmink ${ }^{1}$ and Suzanne J.M.H. Hulscher ${ }^{1}$ \\ ${ }^{1}$ Department of Marine and Fluvial Systems, University of Twente, Drienerlolaan 5, 7522 NB Enschede, the Netherlands \\ ${ }^{2}$ Antea Group, Tolhuisweg 57, 8443 DV Heerenveen, the Netherlands
}

\begin{abstract}
Wave overtopping results in erosion of grass-covered flood defenses which can result in a dike breach. Damages to the dike cover decrease the cover strength and simultaneously increase the hydraulic load on the dike cover. Therefore, damages on the dike cover are vulnerable locations for wave overtopping failure. In this study, the failure probabilities of different types of damages are calculated and compared to the failure probability of a regular dike profile to determine the vulnerability of damages for wave overtopping. The method is applied to a river and lake dike where the model results show that the total failure probability is smaller on the crest and upper slope for the lake dike and higher on the lower slope and at the inner toe. The failure probability increases between a factor 4 and 14 for damaged location where the cover still contains grass vegetation. However, lake dikes are more vulnerable for damages compared to lake dikes in cases where only a bare clay cover is left. In that case, a dike with a damage is almost 3000 more likely to fail compared to a regular dike for a lake dike and around 120 times more likely to fail for a river dike.
\end{abstract}

\section{Introduction}

Wave overtopping is one of the main failure mechanism of flood protective structures. More extreme weather conditions and sea level rise due to climate change will result in more frequent overtopping. Especially structures with a grass cover, such as dikes in Western Europe, are vulnerable for climate change because droughts decrease the strength of the grass cover (Van Ruijven et al., 2010). Grass vegetation dies during extreme droughts and the clay cover underneath the vegetation can crack and significantly damage the dike cover (Van Den Akker et al., 2013).

Damages to the dike cover can also be caused by animals burrows or erosion holes formed by wave overtopping as the results or gradual scour erosion, roll-

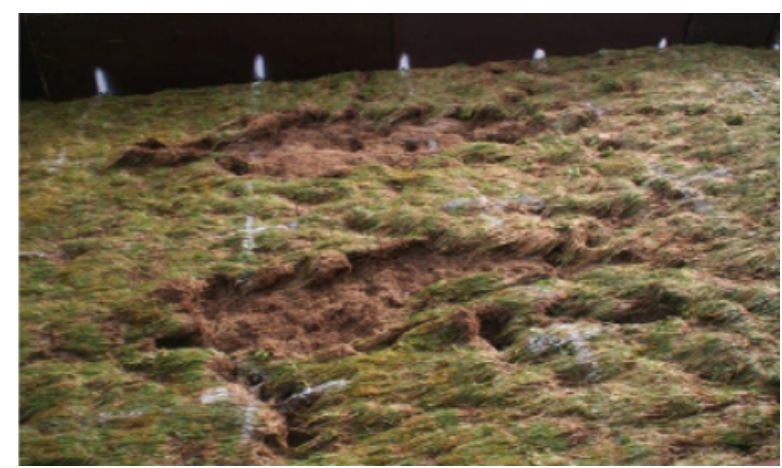

Figure 1. Example of a damage of the dike cover as the result of wave overtopping (Van der Meer et al., 2010).

${ }^{a}$ Corresponding author: v.m.vanbergeijk@utwente.nl DOI 10.3311/FLOODRisk2020.1.20 up or bulging (Le et al., 2017; Van der Meer et al., 2010). Animal burrows decrease the dike cover strength while the grass vegetation is often removed near erosion holes so only the clay cover remains to protect the dike for a breach (Figure 1).

It is unclear how these damages can be included in probabilistic safety assessments of grass-covered dikes. The safety standards in the Netherlands are defined in terms of a maximum probability of failure (ENW, 2017). The probability of failure for each failure mechanism is calculated separately and combined in the total failure probability than must not exceed the maximum failure probability. For wave overtopping, failure is defined as an exceedance of $20 \mathrm{~cm}$ erosion depth ('t Hart et al., 2016). The upper $20 \mathrm{~cm}$ of the grass cover determines the erosion resistance of the dike cover, which decreases in the soil layer underneath where less roots are present (Hoffmans, 2012; Le et al., 2017).

As a first step to include damages in safety assessments, we need to know how damages affect the failure probability by wave overtopping. The failure probability by wave overtopping is often calculated based on the average overtopping discharge, where the dike cover fails once the maximum allowable overtopping discharge is exceeded (EurOtop, 2018; Marijnissen et al., 2019; Vuik et al., 2018). These methods are not suitable for the failure probabilities of damages because of two reasons. Firstly, these methods do not contain a crossdike component and therefore the location of the damage cannot be included in these methods. Secondly, storms with large overtopping waves can have the same 
overtopping discharge as a storm with small waves. However, larger waves can result in more erosion compared to smaller waves and therefore the erosion depth can differ although the overtopping discharge is the same (Van Bergeijk et al. 2019; Van der Meer et al., 2010).

Van Bergeijk et al. (2021) developed a new probabilistic framework to calculate the failure probability along the dike crest and inner slope. This framework uses the water level and wind speed as stochastic variables and is therefore able to distinguish between with storms with the same average overtopping discharge but different wave characteristics. This framework is applicable to damaged dike profiles but has only be applied to a river dike.

The goal of this study is to determine the vulnerability of damages in grass-covered river and lake dikes by overtopping waves. The probabilistic framework of (Van Bergeijk et al., 2021) is used to calculate the failure probabilities of damaged dike profiles. The failure probabilities are calculated for a river and lake dike with different hydraulic characteristics in the Netherlands to determine which type of dike is more vulnerable for damaged dike covers.

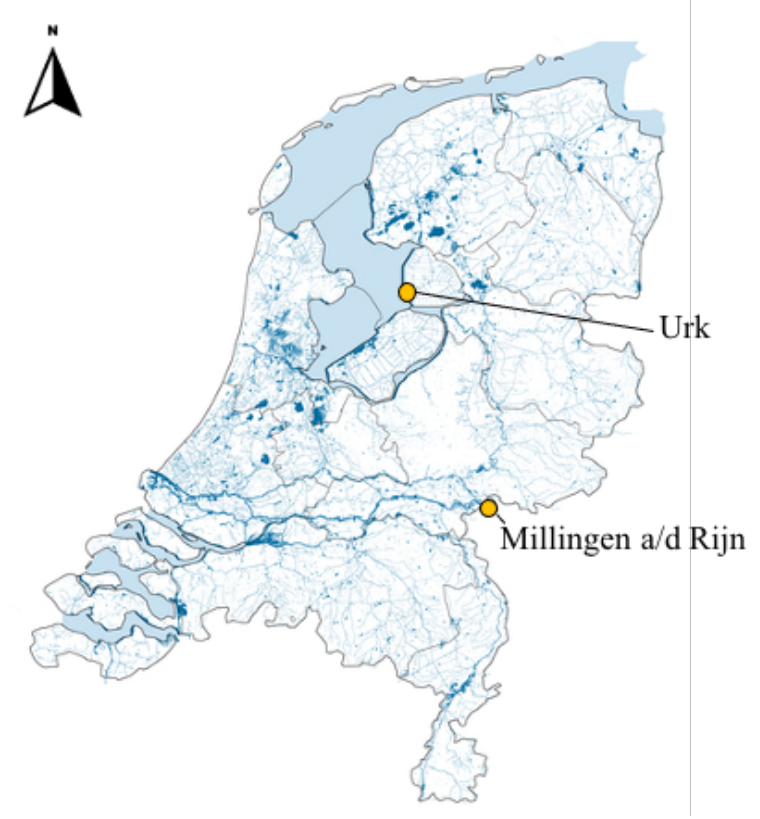

Figure 2. The study sites in the Netherlands: a lake dike near Urk and a river dike near Millingen a/d Rijn. Figure adapted from Oppervlaktewater in Nederland, www.clo.nl.

\section{Methods}

\subsection{Study sites}

We used two study sites in the Netherlands: a lake dike near Urk and a river dike near Millingen a/d Rijn. The dike near Urk is located at the Lake IJssel and the wind statistics of (Caires, 2009) at the measurement station of Schiphol are used for the wind speed. The fetch length for this dike is large since the dominant wind direction is from the northwest (Table 1). The river dike near Millingen a/d Rijn close to the junction of the Rhine, the Pannerdensch canal, and the Waal and has been used in previous studies for wave overtopping failure probabilities (Aguilar-López et al., 2018; Van Bergeijk et al., 2021). At this location, the western wind direction is dominant and the measurement station Deelden is used for the wind speed.

The same dike geometry is used for both dikes, characterized by a crest width of $4.2 \mathrm{~m}$, a slope length of $17.2 \mathrm{~m}$ and a slope steepness of 1:3 for both the outer and inner slope. The crest and inner slope are covered by grass resulting in a friction coefficient $f$ of 0.01 (Van Bergeijk et al., 2019). The outer slope is smooth with a reduction factor $\gamma_{f}=1$ for the run-up and overtopping equations in the EurOtop Manual (EurOtop, 2018).

The Hydra-NL software (Duits et al., 2018) is used to obtain the water levels $h$ with return periods between 10 years and $10^{6}$ years (Table 1 ). The conditional failure probability is calculated for every water level and the total failure probability is obtained by numerical integration over the conditional failure probabilities and the probability density function of the water level (Van Bergeijk et al., 2021).

\begin{tabular}{|l|r|r|}
\hline & \multicolumn{1}{|l|}{ Lake dike } & \multicolumn{1}{l|}{ River dike } \\
\hline Dike height & $3 \mathrm{~m}+\mathrm{NAP}$ & $17.9 \mathrm{~m}+\mathrm{NAP}$ \\
\hline Outer bed level & $-2.71 \mathrm{~m}+\mathrm{NAP}$ & $9.4 \mathrm{~m}+\mathrm{NAP}$ \\
\hline Maximum $h$ & $2.7 \mathrm{~m}+\mathrm{NAP}$ & $17.6 \mathrm{~m}+\mathrm{NAP}$ \\
\hline Minimum $h$ & $0.8 \mathrm{~m}+\mathrm{NAP}$ & $15.8 \mathrm{~m}+\mathrm{NAP}$ \\
\hline Number of $h$ & 20 & 24 \\
\hline Fetch length & $45 \mathrm{~km}$ & $2.8 \mathrm{~km}$ \\
\hline
\end{tabular}

Table 1. Dike characteristics for the lake dike near Urk and the river dike near Millingen a/d Rijn. The maximum and minimum water level $h$ correspond to a return period of $10^{6}$ years and 10 years, respectively.

\subsection{Failure probabilities}

The failure probability by wave overtopping is calculated along the dike crest and the inner slope using the framework of (Van Bergeijk et al., 2021). The water level, the wind speed and the critical velocity $U_{C}$ are used as stochastic variables, where the first two variables describe the variation in hydraulic load and the latter one describes the dike cover strength. The water level and wind speed distribution depend on the study site and the critical velocity distribution depends on the cover type (Aguilar-López et al., 2018; Van Bergeijk et al., 2021).

First, the failure probability conditional to the water level $P_{f \mid h}$ is calculated using a Monte Carlo simulation of $2 \cdot 10^{4}$ storms, where each storm is characterised by a wind speed and critical velocity. The erosion depth along the dike crest and inner slope is calculated using the analytical grass-erosion model (GEM) (Van Bergeijk et al., 2019; Warmink et al., 2020). Failure is defined as the exceedance of $20 \mathrm{~cm}$ erosion depth according to the Dutch safety standards. This results in a conditional failure probability for each water level (Table 1). 
Next, the total failure probability $P_{f}$ is calculated from numerical integration of the conditional failure probabilities and the probability density function of the water level. The cross-dike failure probability - defined as the failure probability along the dike profile - can be computed because the erosion depth is calculated every $0.1 \mathrm{~m}$ on the crest and inner slope. The cross-dike failure probability is calculated for the lake and river dike for an average grass quality (Table 2 ) and the dike characteristics in Table 1.

The hydraulic load on the dike cover changes along the dike profile, for example the turbulence parameter $\omega$ is higher on the crest compared to the inner slope (Bomers et al., 2018) and increases at transitions (Warmink et al., 2020). The formulation of Van Bergeijk et al. (2021) for the turbulence parameter is used in this study with $\omega_{\text {crest }}=2.35, \omega_{\text {slope }}=2.0$ and $\omega_{\text {toe }}=2.75$.

\begin{tabular}{|l|c|}
\hline Dike cover quality & $\boldsymbol{U}_{\boldsymbol{C}}(\mathbf{m} / \mathbf{s})$ \\
\hline Good grass & 6.5 \\
\hline Average grass & 4.0 \\
\hline Poor grass & 2.5 \\
\hline Good clay & 0.85 \\
\hline Poor clay & 0.4 \\
\hline
\end{tabular}

Table 2. Values of the critical velocity $U_{C}$ for different dike cover qualities based on (Verheij et al., 1995)

\subsection{The effect of fetch length}

The main difference between the river and lake dike in this study is the fetch length. The fetch length at the river dike is $2.8 \mathrm{~km}$ compared to a fetch length of $45 \mathrm{~km}$ for the lake dike. The fetch length is used in the Bretschneider equations to calculate the wave height and wave period, which are required to compute the hydraulic load on the dike cover in the GEM (Van Bergeijk et al., 2021). The failure probability is calculated for several fetch lengths between $5 \mathrm{~km}$ and $45 \mathrm{~km}$ for the lake dike. Only the failure probability at the inner toe $P_{f, t o e}$ is calculated to save computational time. A regular dike profile without any dame will fail at the inner toe where the flow velocities are maximal and the hydraulic load increases due to the slope change (Van Bergeijk et al., 2020). The failure probability at the inner toe is calculated for an average grass quality (Table 2) and the turbulence parameter $\omega_{\text {toe }}=2.75$.

\subsection{Damages}

Damages affect the wave overtopping failure probability due to two processes. Firstly, the damage to the dike cover results in (partial) removal of the grass vegetation reducing the cover quality and therefore the critical velocity (Figures 1 and 3). Secondly, a vertical cliff forms at the damage resulting in the formation of a jet that impacts in the impact zone (Figures 1 and 3). The jet increases the hydraulic load on the dike cover in the impact zone. Both processes can result in more erosion and thereby increase the vulnerability of damages for wave overtopping failure.
In this study, the two processes are included in the GEM model. The reduction in cover quality is simulated by adapting the critical velocity to a poor grass quality or to clay in case the complete grass vegetation is removed. The additional load at the damage is modelled using the relation for the turbulence parameter near a damage Wdamage (Van Bergeijk et al., 2021)

$\omega_{\text {damage }}=0.074 U_{C}+2.1$

The failure probability of a damage $P_{f \text {,damage }}$ on the inner slope is calculated for four cover qualities to simulate the reduction in dike cover quality: average grass, poor grass, good clay and poor clay (Table 2). The vulnerability of the damage is determined from the ratio $P_{f \text {,damage }} / P_{f, \text { toe }}$, where $P_{f, \text { toe }}$ is the failure probability of regular dike profile with a good grass quality at the inner toe. The $P_{f \text {,damage }}$ is calculated along the slope to determine what location along the slope is most vulnerable for damages.

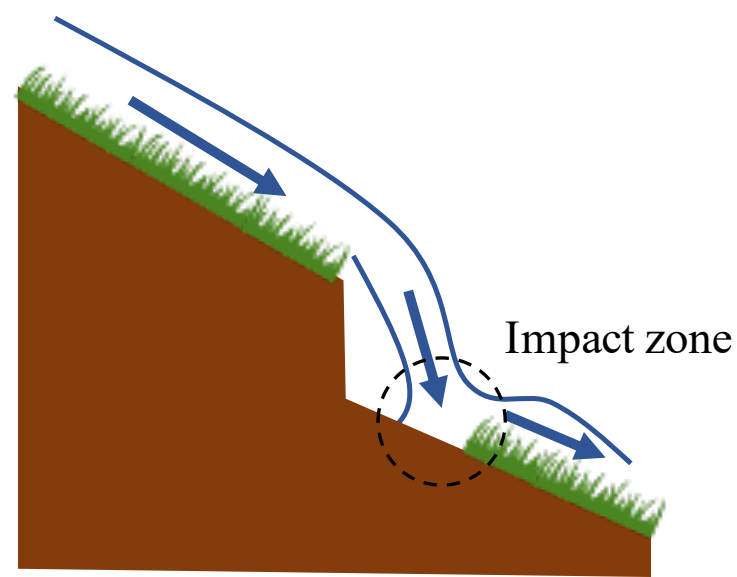

Figure 3. Damages on the inner slope lead to (partial) removal of the grass cover and a vertical cliff. Flow over the vertical cliff results in the formation of a jet that impacts in the impact zone indicated by the black dashed circle.

\section{Results}

\subsection{Fragility Curves}

The fragility curves show the failure probability conditional to the water level $P_{f \mid h}$ as function of the free crest height $R_{c}$, defined as the height difference between the water level and the dike height. A steep fragility curve means that the failure probability has a high predictability (Marijnissen et al., 2019). In this study, the steepness is related to the amount of wave overtopping. Since the waves on a river a relatively small, overtopping only occurs when the water level is sufficiently high. The waves on a lake are higher and wave overtopping is also possible for smaller water levels.

The conditional failure probability of the lake dike is higher compared to the river dike for a free crest height. The average overtopping discharge at a specific free crest height is larger for a lake dike compared to the river dike, because the waves are higher on the lake due to a larger fetch length. The higher overtopping discharge leads to 
more and large overtopping waves which increases the load on the dike cover and thereby the dike is more likely to fail.

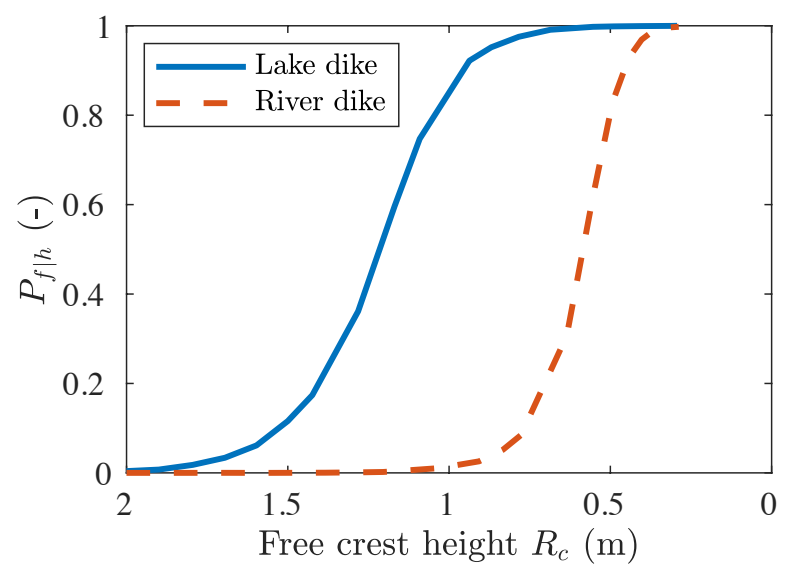

Figure 4. The conditional failure probability $P_{f \mid h}$ at the inner toe as function of the free crest height $R_{c}$ for the lake and river dike.

\subsection{Cross-dike failure probability}

The cross-dike failure probability decrease on the crest because of friction and increase on the inner slope due to gravitational acceleration (Van Bergeijk et al., 2019) (Figure 5). The sudden jumps in the failure probability at the end of the crest and the end of the inner slope are related to the variation in the turbulence parameter, which is smaller for the slope compared to the crest and inner toe (Section 2.2). Although the conditional failure probabilities are higher for the lake dike, the total failure probability is smaller on the crest and upper slope compared to the river dike. This is related to the probability distribution of the water level, the high water levels corresponding to small free crest heights have a lower probability of occurrence for the lake dike compared to the river dike.

The lake and river dike are both most likely to fail at theinner toe with a failure probability of $9.2 \cdot 10^{-3}$ and $91.4 \cdot 10^{-3}$, respectively. The increase in the failure probability on the slope is larger for the lake dike, because

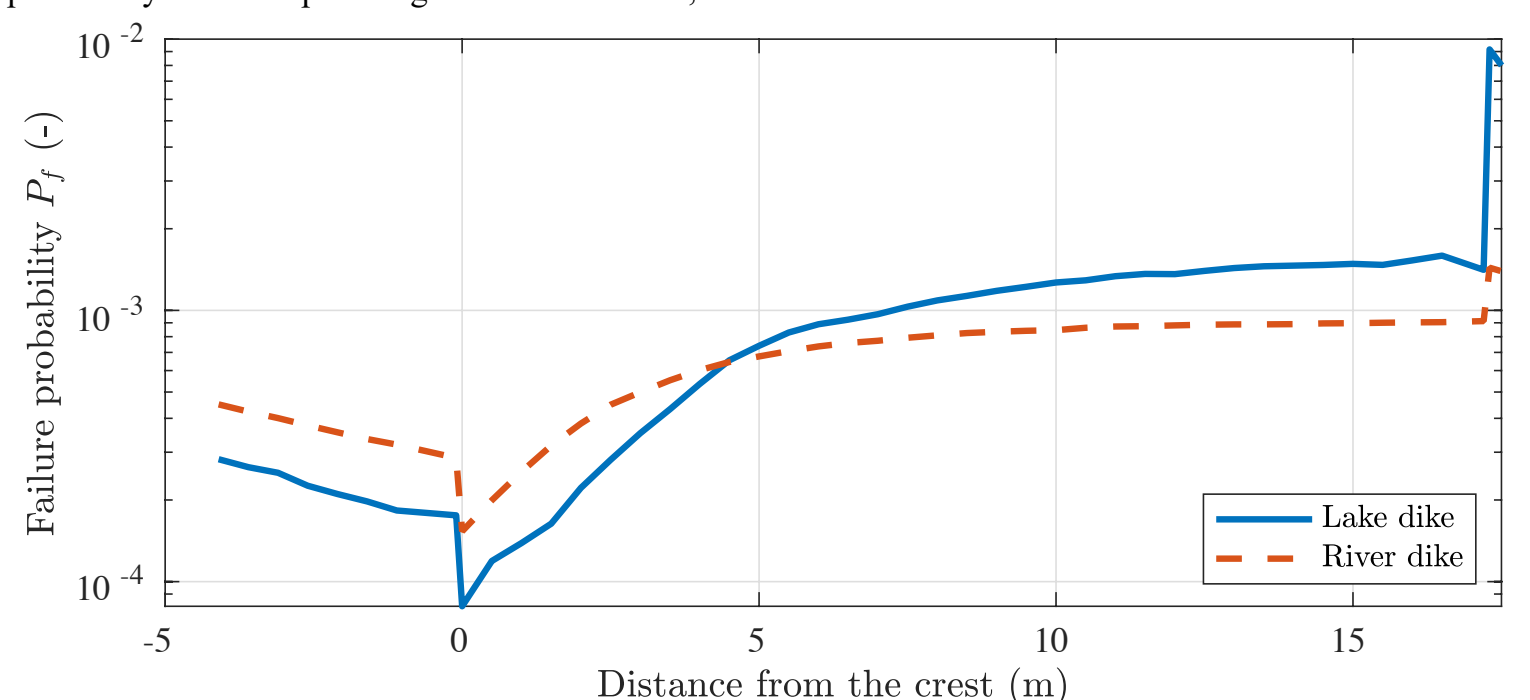

Figure 5. The cross-dike failure probabilities for the lake and river dike for an average grass quality. the larger overtopping waves accelerate more on the inner slope. This is related to the bottom friction, which has a relatively larger effect on smaller waves compared to larger waves (Van Bergeijk et al., 2019).

\subsection{The effect of the fetch length}

The failure probability increases with the fetch length from $2.4 \cdot 10^{-6}$ for a fetch length of $5 \mathrm{~km}$ to $6.8 \cdot 10^{-3}$ for a fetch length of $45 \mathrm{~km}$ (Figure 6). This shows that the fetch length has a large influence on the failure probability. The failure probability is especially sensitive for the fetch length for small fetch lengths. The failure probability increases with almost a factor 10 when the fetch length increases from 5 tot $10 \mathrm{~km}$, but increase only $30 \%$ from a fetch length $40 \mathrm{~km}$ to $45 \mathrm{~km}$ which is usually within the error range of the failure probability.

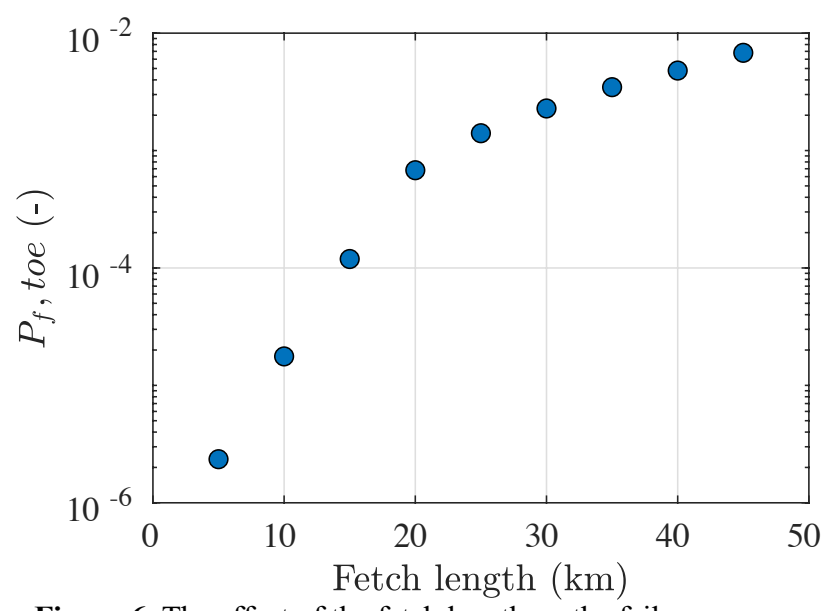

Figure 6. The effect of the fetch length on the failure probability at the inner toe $P_{f, t o e}$ for the lake dike with an average grass quality. 

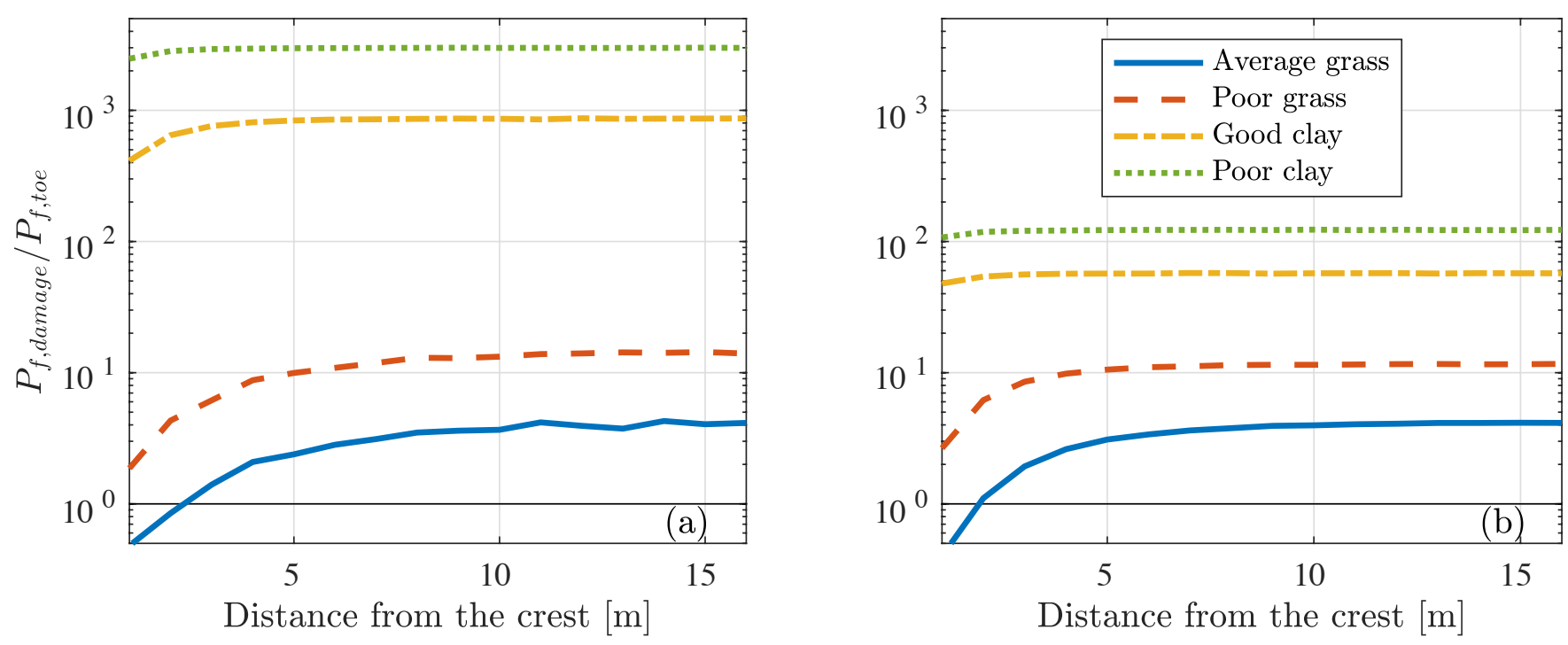

Figure 7. The ratio $P_{f \text {,damage }} P_{f, \text { toe }}$ along the inner slope with $P_{f \text {,damage }}$ the failure probability of a damaged location for the four cover qualities and $P_{f, t o e}$ the failure probability at the inner toe for a good grass cover for (a) the lake dike and (b) the river dike.

\subsection{Vulnerability of damages}

The ratio between the failure probability of a damage and the inner toe shows that a damage is more likely to fail except for a damage on the upper slope with an average grass quality (Figure 7). The failure probability is higher for a damage on the lower slope compared to a damage on the upper slope due to the higher flow velocity at the lower slope.

The vulnerability of damages with a poor and average grass quality is similar for a river and lake dike where the ratio is of the same magnitude (Table 3). However, damages with a solely a clay cover are more vulnerable on a lake dike compared to a river dike where the ratio is much higher for the lake dike. Small overtopping waves are already able to erode clay due to the low critical velocity (Table 2 ) and the erosion rate of clay is larger compared to grass, which means that the erosion depth of $20 \mathrm{~cm}$ for clay is reached with a small number of overtopping waves (Verheij et al., 1995). The fragility curve shows that significant wave overtopping start for the lake dike at already around a free crest height of $2 \mathrm{~m}$ compare to a free crest height of $1 \mathrm{~m}$ for the river dike. Therefore, the clay covers are likely to fail for a wide range of free crest heights $\left(R_{c}<2 \mathrm{~m}\right)$ resulting in a high failure probability.

\begin{tabular}{|c|c|c|}
\hline Cover quality & Lake dike & River dike \\
\hline Average grass & 4 & 4 \\
\hline Poor grass & 14 & 12 \\
\hline Good clay & 868 & 57 \\
\hline Poor clay & 2989 & 122 \\
\hline
\end{tabular}

Table 3. The maximum ratio $P_{f \text {,damage }} / P_{f, \text { toe }}$ for the four cover qualities for the lake dike and river with $P_{f \text { damage }}$ the failure probability of a damaged location and $P_{f, t o e}$ the failure probability at the inner toe for a good grass cover.

\section{Conclusions}

In this study, we determined the vulnerability of damages for wave overtopping failure. The vulnerability of a damage on the inner slope is similar for a river dike and lake dike when the damaged spot still contains some grass vegetation. However, once the grass cover is eroded and only a bare clay cover is left at the damaged location, the damage is more vulnerable for a lake dike compared to the river dike. For a river dike, a damage with a poor clay cover is 3000 times more likely to fail compared to a regular dike profile. This means that damages without a grass cover are a high risk for failure of lake dikes and therefore inspection of animal burrows and other damages is important for lake dikes.

The fragility curve for a lake dike is less steep compared to a river dike and significant overtopping already starts at small water levels. However, the total failure probability for wave overtopping of a river and lake dike is of similar magnitude because the high water levels have a smaller occurrence probability for the lake dike compared to the river dike.

\section{Acknowledgements}

This research was funded by the Netherlands Organisation for Scientific Research (NWO), research programme All-Risk with project number P15-21.

\section{References}

1. 't Hart, R., de Bruijn, H., \& de Vries, G. (2016). Fenomenologische beschrijving, Faalmechanismen WTI (in Dutch). The Netherlands.

2. Aguilar-López, J. P., Warmink, J. J., Bomers, A., Schielen, R. M. J. J., \& Hulscher, S. J. M. H. (2018). Failure of grass covered flood defences with roads on top due to wave overtopping: A probabilistic assessment method. Journal of Marine Science and Engineering, 6(3), 1-28. 
https://doi.org/10.3390/jmse6030074

3. Bomers, A., Aguilar-López, J. P., Warmink, J. J., \& Hulscher, S. J. M. H. (2018). Modelling effects of an asphalt road at a dike crest on dike cover erosion onset during wave overtopping. Natural Hazards, 93(1), 1-30. https://doi.org/10.1007/s11069-0183287-y

4. Caires, S. (2009). Extreme wind statistics for the Hydraulic Boundary Conditions for the Dutch primary water defences. SBW-Belastingen: Phase 2 of subproject "Wind Modelling." Technical Report, Deltares, 1200264-005.

5. Duits, M. T., \& Kuijper, B. (2018). Hydra-NLSysteemdocumentatie - Versie 2.4. HKV, Lelystad, Netherlands. HKV-rapport PR3598.

6. ENW. (2017). Fundamentals of Flood Protection. The Hague, The Netherlands. Retrieved from https://www.enwinfo.nl/images/pdf/Grondslagen/Gr ondslagenEN lowresspread.pdf

7. EurOtop. (2018). Manual on wave overtopping of sea defences and related structures. An overtopping manual largely based on European research, but for worldwide application. www.overtoppingmanual.com. Retrieved from www.overtoppingmanual.com.

8. Hoffmans, G. J. C. M. (2012). The influence of turbulence on soil erosion. Eburon Uitgeverij BV.

9. Le, H. T., Verhagen, H. J., \& Vrijling, J. K. (2017). Damage to grass dikes due to wave overtopping. Natural Hazards, 86(2), 849-875. https://doi.org/10.1007/s11069-016-2721-2

10. Marijnissen, R., Kok, M., Kroeze, C., \& van LoonSteensma, J. (2019). Re-evaluating safety risks of multifunctional dikes with a probabilistic risk framework. Natural Hazards and Earth System Sciences, 19(4), 737-756. https://doi.org/10.5194/nhess-2018-295

11. Van Bergeijk, V. M., Verdonk, V. A., Warmink, J. J., \& Hulscher, S. J. M. H. (n.b). The cross-dike failure probability by wave overtopping over grasscovered and damaged dikes. Submitted.

12. Van Bergeijk, V. M., Warmink, J. J., Frankena, M., \& Hulscher, S. J. M. H. (2019). Modelling Dike Cover Erosion by Overtopping Waves: The Effects of Transitions. In T. Goseberg, Nils; Schlurmann (Ed.), Coastal Structures 2019 (pp. 1097-1106). Karlsruhe: Bundesanstalt für Wasserbau. https://doi.org/10.18451/978-3-939230-64-9_110

13. Van Bergeijk, V. M., Warmink, J. J., \& Hulscher, S. J. M. H. (2020). Modelling the Wave Overtopping Flow over the Crest and the Landward Slope of Grass-Covered Flood Defences. Journal of Marine Science and Engineering, 8(7), 489. https://doi.org/10.3390/jmse8070489

14. Van Bergeijk, V. M., Warmink, J. J., Van Gent, M. R. A., \& Hulscher, S. J. M. H. (2019). An analytical model of wave overtopping flow velocities on dike crests and landward slopes. Coastal Engineering, 149(March), 28-38. https://doi.org/10.1016/j.coastaleng.2019.03.001

15. Van Den Akker, J. J. H., Hendriks, R. F. A., Frissel, J. Y., Oostindie, K., \& Wesseling, J. G. (2013).
Gedrag van verdroogde kades. Fase B, C, D: Ontstaan en gevaar van krimpscheuren in klei-en veenkades (in Dutch). Wageningen, the Netherlands.

16. Van der Meer, J. W., Hardeman, B., Steendam, G. J., Schüttrumpf, H., \& Verheij, H. (2010). Flow depths and velocities at crest and landward slope of a dike, in theory and with the wave overtopping simulator. Coastal Engineering Proceedings, 1(32), 10.

17. Van Ruijven, J., \& Berendse, F. (2010). Diversity enhances community recovery, but not resistance, after drought. Journal of Ecology, 98(1), 81-86. https://doi.org/10.1111/j.1365-2745.2009.01603.x

18. Verheij, H. J., Meijer, D. G., Kruse, G. A. M., Smith, G. M., \& Vesseur, M. (1995). Investigation of the strength of a grass cover upon river dikes. Report Q1878, Deltares, Delft.

19. Vuik, V., van Vuren, S., Borsje, B. W., van Wesenbeeck, B. K., \& Jonkman, S. N. (2018). Assessing safety of nature-based flood defenses: Dealing with extremes and uncertainties. Coastal Engineering, 139(May), 47-64. https://doi.org/10.1016/j.coastaleng.2018.05.002

20. Warmink, J. J., Van Bergeijk, V. M., Frankena, M., Van Steeg, P., \& Hulscher, S. J. M. H. (2020). Modelling Transitions in Grass Covers to Quantify Wave Overtopping Erosion. In Coastal Engineering Proceedings 2020 (pp. 1-8). https://doi.org/10.9753/icce.v36v.papers.39 